(๑) Entomologica Fennica. 29 June 1994

\title{
Hydrovatus asymmetricus sp. n. (Coleoptera, Dytiscidae) - an enigmatic species from Southeast Asia
}

\author{
Olof Biström \& Günther Wewalka
}

\begin{abstract}
Biström, O. \& Wewalka, G. 1994: Hydrovatus asymmetricus sp. n. (Coleoptera, Dytiscidae) — an enigmatic species from Southeast Asia. — Entomol. Fennica 5:103-104.

Hydrovatus asymmetricus sp. $\mathrm{n}$. is described from Kamputchea, Burma and Indonesia (Java), and its enigmatic systematic position is discussed.

Olof Biström, Zoological Museum, P.O. Box 17 (N. Järnvägsgatan 13), FIN-00014 University of Helsinki, Finland

Günther Wewalka, Kandlgasse 19-21, A-1070 Vienna, Austria
\end{abstract}

Received 16 June 1993, accepted 20 June 1993

After the revision of the genus Hydrovatus Motschulsky had been accepted for publication (Biström 1994), a few additional Hydrovatus specimens were discovered, and they proved to belong to a new species described below.

\section{Hydrovatus asymmetricus sp. $\mathrm{n}$.}

Type locality: Bogor Botanical Garden, Java, Indonesia. Type material: Holotype, male: W-Jawa, Bogor Bot. Garden, artificial pond, 12.1, 1987 (J2), leg. Jäch (Nat. Hist. Mus., Vienna). - Paratypes (females): Pegu/Museum Paris coll. Maurice Régimbart 1908/humerosus Rég. n.sp. typ (1 ex. Mus. Paris; never described by Régimbart); Battambang 1943/Indo Chine Coll. Dussault/Naturhist. Museum Basel (1 ex. Nat. Hist. Mus., Basel, 1 ex. Zool. Mus. Helsinki, 1 ex. coll. Wewalka).

Etymology: The species name asymmetricus refers to the asymmetric shape of the penis.

Diagnosis: Easily recognized from all other Hydrovatus species by small body size in combination with globular shape of body and strongly asymmetric penis apex. (Note that association of sexes with the same species is slightly uncertain because the examined material was sampled in distant localities.)

Description: Length of body $1.62 \mathrm{~mm}$, breadth $1.14 \mathrm{~mm}$. Habitus (Fig. 1). Body remarkably globular. - Head pale ferruginous, practically impunctate, rather shiny, surface with rather fine but clearly discernible reticulation. Frontal outline rounded, medially slightly straightened. Between eyes narrowly margined (Fig. 2). Antenna slender. Beginning with third segment, antennal segments gradually longer towards apex (Fig. 3). - Pronotum pale ferruginous, punctation absent to rather indistinct. At pronotal margins indistinct and quite dense punctures may be discerned. Rather shiny, although finely microsculptured (meshes almost on entire disc clearly discernible). Lateral outline of pronotum slightly rounded. - Elytra dark ferruginous to ferruginous, laterally palest but without distinct colour pattern. Main colour of elytra slightly darker than main colour of pronotum and head. Punctation rather fine, slightly sparse and posteriorly rather indistinct. Rows of punctures absent, except lateral row, which may be discerned although irregular and indistinct. Rather shiny, although microsculptured. Meshes of microsculpture partly reduced, indistinct. Epipleuron pale ferruginous, almost impunctate. With fine, rather indistinct, scattered microsculpture. - Ventral surface pale ferruginous to ferruginous. Punctation rather fine to fine, quite dense, except on apical sternites; almost impunctate. Rather shiny, with indistinct 

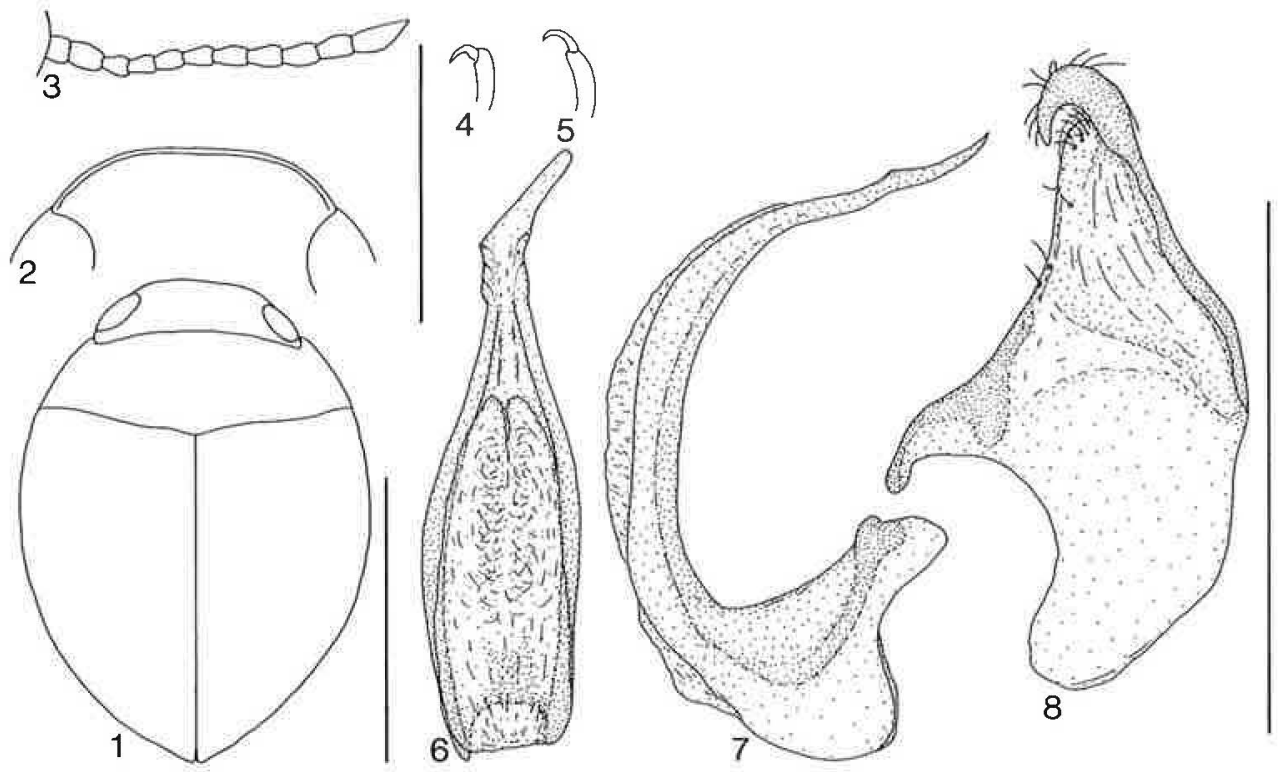

Figs. 1-8. Hydrovatus asymmetricus sp. n. 1, habitus; 2, male head, frontal aspect; 3, male antenna; 4, male protarsal claw; 5, male mesotarsal claw; 6 , penis, dorsal aspect; 7 , penis, lateral aspect; 8 , paramere. — Left top scale $0.5 \mathrm{~mm}$, head, antenna, claws; left bottom scale $1 \mathrm{~mm}$, habitus; right scale $0.4 \mathrm{~mm}$, genitalia.

scattered microsculpture. Prosternal process laterally quite distinctly margined. Medial surface almost flat and densely punctate. Stridulatory apparatus absent. - Legs pale ferruginous. Proand mesotarsus somewhat enlarged. Protarsal claws short, basally slightly thickened (Fig. 4). Mesotarsal claws slender and symmetric, clearly prolonged (Fig. 5). - Male genitalia: Figs. 6-8. Penis apex distinctly asymmetric.

Female: Possibly larger than male: Length of body $1.80-1.84 \mathrm{~mm}$, breadth $1.32-1.34 \mathrm{~mm}$. Protarsal claws quite slender, basally not thickened; similar to mesotarsal claws.

Distribution: Burma, Kamputchea, Indonesia: Java. Java.

Biology: Collected from an artificial pond in

Hydrovatus asymmetricus is as enigmatic morphologically as it is geographically. Firstly, it is morphologically difficult to place in any of the recently introduced species groups. Secondly, its occurrence in SE Asia is surprising if it is placed in the species group it most resembles.

Provisionally $H$. asymmetricus is associated with the species group $H$. turbinatus, in which only one species (H. turbinatus Zimmermann) is recognized. The species group was thus far known only from South America. Characters in common are: 1. Penis apex (dorsal aspect) asymmetric, although weakly so in $H$. turbinatus. 2. Soft medial part of penis similar. 3. Beginning with third antennal segment the segments gradually longer towards apex. 4 . Male mesotarsal claws prolonged. Differences are: 1. Prolonged male mesotarsal claws unequal in $H$. turbinatus while equal in length in $H$. asymmetricus. 2. Parameral apex distinctly hooked in $H$. asymmetricus, while not so in $H$. turbinatus, although apex sclerotized and modified. Whether parameral apical modifications are homologous or not in the two species is unclear.

If the apical structures of the paramere in the two species are interpreted as homologous (both hooked), this kind of modification most probably evolved before the opening of the Atlantic Ocean. In the revision this modification was suggested to have evolved after the separation of South America and "the Old World". Migration to South America via the land bridge between Asia and North America is regarded as improbable but cannot be excluded.

\section{Reference}

Biström, O. 1994: Taxonomic revision of the genus Hydrovatus Motsculsky (Coleoptera, Dytiscidae). Entomol. Basilensia (in press). 